\title{
Clerodane Diterpenoids with Anti-hyperglycemic Activity from Tinospora crispa
}

\author{
Yuan Gao $\cdot$ Yan-Fen Niu $\cdot$ Fei Wang $\cdot$ \\ Ping Hai $\cdot$ Fang Wang $\cdot$ Yin-Dong Fang • \\ Wen-Yong Xiong $\cdot$ Ji-Kai Liu
}

Received: 30 August 2016/ Accepted: 28 September 2016/Published online: 17 October 2016

(C) The Author(s) 2016. This article is published with open access at Springerlink.com

\begin{abstract}
Four new clerodane diterpenoids, tinosporols A-C (2-4) and tinosporoside A (5), together with six known analogues were isolated from the vines of Tinospora crispa. Their structures were established by extensive spectroscopic analysis. The relative configuration at $\mathrm{C}-12$ in the known diterpenoid borapetoside $\mathrm{E}(\mathbf{1})$, the major component of the plant, was firstly established with the aid of molecular model. Compound $\mathbf{1}$ significantly reduced serum glucose levels at dosedependent manners in alloxan-induced hyperglycemic mice and $\mathrm{db} / \mathrm{db}$ type 2 diabetic mice.
\end{abstract}

Yuan Gao and Yan-Fen Niu contributed equally to this article.

Electronic supplementary material The online version of this article (doi:10.1007/s13659-016-0109-3) contains supplementary material, which is available to authorized users.

Y. Gao · Y.-F. Niu $\cdot$ F. Wang · F. Wang · W.-Y. Xiong (ه) J.-K. Liu

State Key Laboratory of Phytochemistry and Plant Resources in West China, Kunming Institute of Botany, Chinese Academy of Sciences, Kunming 650201, Yunnan, People's Republic of China e-mail: xiong.wenyong@mail.kib.ac.cn

\section{Y. Gao · P. Hai}

Department of Chemical Engineering, Yibin University,

Yibin 644000, People's Republic of China

Y. Gao - F. Wang · P. Hai · Y.-D. Fang

BioBioPha Co., Ltd, Kunming 650201, People's Republic of China

Y.-F. Niu - F. Wang

Graduate University of Chinese Academy of Sciences,

Beijing 100049, People's Republic of China

Y.-F. Niu

Yunnan University, Kunming 650091, People's Republic of China

J.-K. Liu (ه)

School of Pharmaceutical Sciences, South-Central University for Nationalities, Wuhan 430074, China

e-mail: jkliu@mail.kib.ac.cn 


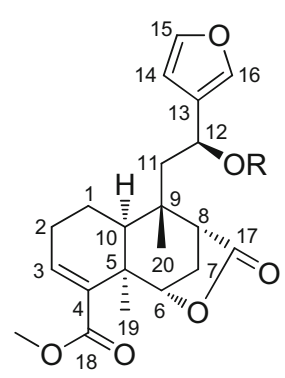

$1 \mathrm{R}=\beta-\mathrm{D}-\mathrm{Gl} \mathrm{C}$

$6 R=\beta-D-G l c-(6 \rightarrow 1)-\beta-D-G l c 10 R=\beta-D-G l c$

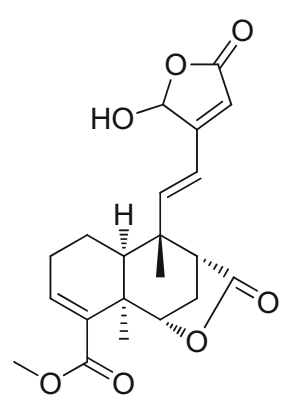

4

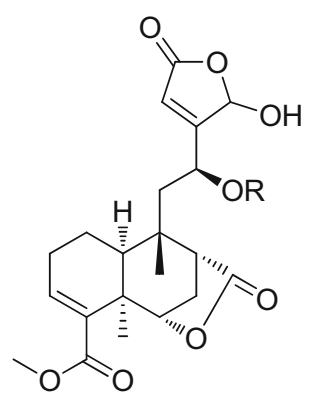

$2 \mathrm{R}=\mathrm{H}$

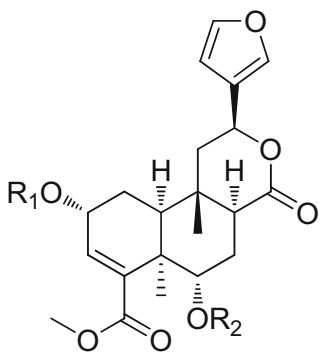

$5 \mathrm{R}_{1}=\beta-\mathrm{D}-\mathrm{Gl} \mathrm{c}, \mathrm{R}_{2}=\mathrm{H}$

$7 \mathrm{R}_{1}=\mathrm{H}, \mathrm{R}_{2}=\beta-\mathrm{D}-\mathrm{Gl} \mathrm{c}$<smiles>COC(=O)C1=CC(O)C[C@H]2C[C@@]3(OC(C)=O)C=C[C@]4(OC(=O)O[C@H](c5ccoc5)C[C@H]43)C12</smiles>

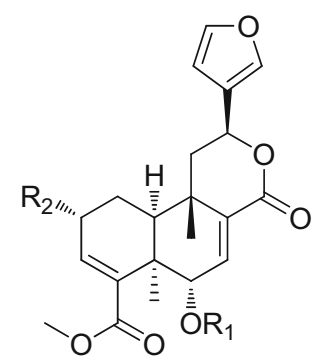

$8 \mathrm{R}_{1}=\beta-\mathrm{D}-\mathrm{Gl}, \mathrm{R}, \mathrm{R}_{2}=\mathrm{H}$

$9 \mathrm{R}_{1}=\beta-\mathrm{D}-\mathrm{Glc}, \mathrm{R}_{2}=\mathrm{OH}$

Keywords Anti-hyperglycemia

Tinospora crispa (Menispermaceae) is a defoliation vine mainly distributed in Cambodia, India, Indonesia, Laos, Malaysia, Myanmar, Philippines, Thailand, and South China [1]. This plant is a prolific source of anti-hyperglycemic clerodane diterpenoids, among which borapetoside $\mathrm{C}$ was found to be an effective agent for the treatment of type 2 diabetes mellitus (T2DM) [2, 3].

T2DM is a chronic metabolic disorder characterized by deregulation of glucose and lipid metabolism [4]. Currently, approximately 150 million people are suffered with diabetes worldwide, and this population could increase up to 300 million by 2025 . The estimated prevalence of diabetes among a representative sample of Chinese adults was $11.6 \%$ [5]. Numerous drugs, such as rosiglitazone (ROS) and metformin (MET), have been used in the treatment of T2DM. However, treatment with synthetic drugs has been reported to lead to various side effects [6]. Therefore, searching for better agents from herbs or natural products is necessary [7]. Traditional Chinese medicines (TCMs), which have been used by the Chinese to treat illnesses for thousands of years, are combination drugs comprising several different active compounds. TCMs are better at controlling complex disease systems such as diabetes and are less prone to causing drug resistance development [8]. As part of a BioBioPha [http://www.chemlib.cn] objective to assemble a large-scale natural products library valuable in the discovery of new drug leads from TCMs [9-11], phytochemical investigation on the vines of T. crispa led to the isolation of four new clerodane diterpenoids, tinosporols A-C (2-4) and tinosporoside A (5), together with six known analogues. The following describes the isolation and structural elucidation of compounds 1-5, and the antihyperglycemic activity of borapetoside $\mathrm{E}$.

\section{Results and Discussion}

The $95 \%$ ethanolic extract of air-dried and powdered vines of $T$. crispa was chromatographed using silica gel, MCI CHP-20, and Sephadex LH-20 column chromatography (CC), preparative TLC, and MPLC to yield four new (2-5) and six known (1, 6-10) cis-clerodane type diterpenoids. 
The known diterpenoids were identified as borapetoside $\mathrm{E}$ (1) [12], borapetoside D (6) [12], borapetoside B (7) [2], borapetoside F (8) [13], dehydroborapetoside B (9) [14], and rumphioside $\mathrm{F}$ (10), [15] respectively. Although borapetoside $\mathrm{E}(\mathbf{1})$, the major component of the plant, had been reported [12], the configuration at $\mathrm{C}-12$ in this molecule was not determined. The relative configuration at C-12 in $\mathbf{1}$ was established spectroscopically based on computer-generated 3D drawing with minimized energy by MM2 calculation in this study.

Compound 1 has spectral data (MS, ${ }^{1} \mathrm{H}$ and ${ }^{13} \mathrm{C}$ NMR) identical to those of the known compound borapetoside $\mathrm{E}$ [12], however, the stereochemistry at C-12 in this molecule was still undetermined. In the ${ }^{1} \mathrm{H}$ NMR spectrum (Table 1), two $J$ values $\left({ }^{3} J_{12,11 \text { pro- } R^{*}}=10.0 \mathrm{~Hz} ;{ }^{3} J_{12,11 \text { pro- } S^{*}} \approx 0 \mathrm{~Hz}\right)$ were contrasted with the coupling constants usually found in freely rotating systems (generally 5-8 Hz), indicative of that $\mathrm{C}(11)-\mathrm{C}(12)$ bond bearing two large groups (butenolide and naphthane) can not rotate freely. In a Newman projection (Fig. 1), the trans relationship of H-11pro- $R^{*}$ and $\mathrm{H}-12$ was implied by a large coupling constant $\left({ }^{3} J_{12,11 \text { pro- } R^{*}}=\right.$ $10.0 \mathrm{~Hz}$ ), while the dihedral angle of $\mathrm{H}-11$ pro- $S * / \mathrm{C}-11 /$ C-12/H-12 was supposed to be around $90^{\circ}$, as indicated by

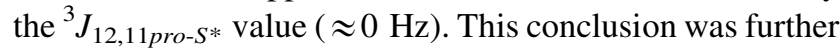
supported by strong correlation of $\mathrm{H}-12 \leftrightarrow \mathrm{H}-11$ pro- $S^{*}$ and no correlation of $\mathrm{H}-12 \leftrightarrow \mathrm{H}-11$ pro- $R^{*}$. In the MM2-optimized stereoview of $\mathbf{1}$ (Fig. 1), significant ROESY correlations of H-12↔H-8, H-12↔H-11pro-S*, and H-11pro$S^{*} \leftrightarrow \mathrm{H}-10$ indicated that $\mathrm{H}-8, \mathrm{H}-12$, and $\mathrm{H}-11$ pro- $S^{*}$ are cofacial. Meanwhile, correlations of H-11pro- $R * \leftrightarrow \mathrm{H}-1$ and $\mathrm{H}-11$ pro- $R^{*} \leftrightarrow \mathrm{H}_{3}-20$, and no correlations of $\mathrm{H}-11$ pro$R * \leftrightarrow \mathrm{H}-10$ and H-11pro-S*↔H-1 revealed that $\mathrm{H}-1,11$ pro-

Table $1{ }^{1} \mathrm{H}$ NMR spectroscopic data for $\mathbf{1}$ and $\mathbf{2}$

\begin{tabular}{|c|c|c|c|}
\hline No. & $\mathbf{1}^{\mathrm{a}}$ & $2^{b}$ & $2^{c}$ \\
\hline $1 \alpha$ & $1.69, \mathrm{~m}$ & 1.94, overlap & 1.82-1.92, overlap \\
\hline $1 \beta$ & $1.67, \mathrm{~m}$ & 1.94, overlap & 1.82-1.92, overlap \\
\hline $2 \alpha$ & $2.06, \mathrm{~m}$ & $2.34 / 2.30, \mathrm{~m}$ & $2.30 / 2.26, \mathrm{~m}$ \\
\hline $2 \beta$ & $2.16, \mathrm{~m}$ & $2.41 / 2.44 \operatorname{td}(9.4,2.8 / 9.4,3.1)$ & $2.34, \mathrm{td}(9.1,3.0) / 2.38, \mathrm{~m}$ \\
\hline 3 & $6.86, \mathrm{t}(3.8)$ & $7.06, \mathrm{t}(3.8)$ & $6.96, \mathrm{t}(3.8)$ \\
\hline 6 & $5.60, \mathrm{~d}(6.1)$ & $5.57 / 5.55, \mathrm{~d}(6.1)$ & $5.28, \mathrm{~d}(6.1)$ \\
\hline $7 \alpha$ & 2.03 , ddd $(12.5,6.1,5.6)$ & 2.25/2.23, ddd $(12.6,6.4,6.1)$ & 2.20, ddd $(12.5,6.1,5.1)$ \\
\hline $7 \beta$ & $1.88, \mathrm{~d}(12.5)$ & $2.00 / 1.99, \mathrm{~d}(12.6)$ & $1.84, \mathrm{~d}(12.5)$ \\
\hline 8 & $3.21, \mathrm{~d}(5.6)$ & $2.59 / 2.61, \mathrm{~d}(6.4)$ & $2.53, \mathrm{~d}(5.1) / 2.57, \mathrm{~m}$ \\
\hline 10 & 1.44, dd $(5.5,4.4)$ & $1.45, \mathrm{t}(3.6) / 1.49, \mathrm{dd}(4.6,2.3)$ & $1.31 / 1.39$, brs \\
\hline 11 pro- $R^{*}$ & 2.29, dd $(14.9,10.0)$ & 1.94, overlap/2.06, dd $(15.0,9.1)$ & 1.83/1.92, overlap \\
\hline 11 pro-S* & 1.88, brd $(14.9)$ & $1.63 / 1.84, \mathrm{~d}(15.1 / 15.0)$ & $1.47 / 1.71, \mathrm{~d}(14.9 / 14.1)$ \\
\hline 12 & 5.81, brd $(10.0)$ & $4.85 / 4.94, \mathrm{~d}(8.4 / 9.1)$ & 4.69/4.72, m \\
\hline 14 & $6.97, \mathrm{~d}(1.2)$ & $6.07 / 6.06, \mathrm{~s}$ & $5.93 / 6.02, \mathrm{~s}$ \\
\hline 15 & $7.61, \mathrm{t}(1.6)$ & & \\
\hline 16 & 8.20, brs & $6.25, \mathrm{~s}$ & $6.14 / 6.13$, brs \\
\hline 19 & $1.35, \mathrm{~s}$ & $1.34, \mathrm{~s}$ & $1.23, \mathrm{~s}$ \\
\hline 20 & $1.34, \mathrm{~s}$ & $1.26 / 1.27, \mathrm{~s}$ & $1.17 / 1.18, \mathrm{~s}$ \\
\hline $\mathrm{OMe}$ & $3.66, \mathrm{~s}$ & $3.74 / 3.73, \mathrm{~s}$ & $3.67, \mathrm{~s}$ \\
\hline \multicolumn{4}{|l|}{$\mathrm{CH}_{3} \mathrm{CO}$} \\
\hline $12-\mathrm{OH}$ & & & $5.37 / 5.30, \mathrm{~d}(5.4 / 5.9)$ \\
\hline $16-\mathrm{OH}$ & & & 7.89/7.86, brs \\
\hline $1^{\prime}$ & $4.96, \mathrm{~d}(7.8)$ & & \\
\hline $2^{\prime}$ & $4.08, \mathrm{t}(8.2)$ & & \\
\hline $3^{\prime}$ & $4.16, \mathrm{t}(8.7)$ & & \\
\hline $4^{\prime}$ & $4.19, \mathrm{t}(8.9)$ & & \\
\hline $5^{\prime}$ & $3.83, \mathrm{~m}$ & & \\
\hline $6^{\prime}$ & 4.30, dd $(11.5,5.7)$ & & \\
\hline & 4.52, dd $(11.5,2.4)$ & & \\
\hline
\end{tabular}

\footnotetext{
${ }^{\text {a }}$ Measured in pyridine- $d_{5}\left(\delta_{\mathrm{H}} 8.71 \mathrm{ppm}\right)$

b Measured in $\mathrm{CDCl}_{3}\left(\delta_{\mathrm{H}} 7.26 \mathrm{ppm}\right)$

c Measured in DMSO- $d_{6}\left(\delta_{\mathrm{H}} 2.49 \mathrm{ppm}\right)$
} 
positive correlation:

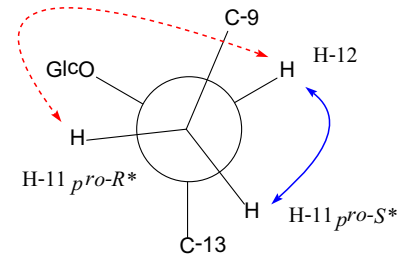
no correlation:

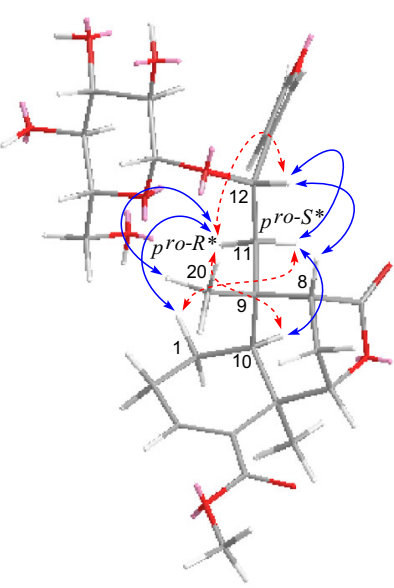

Fig. 1 Key ROESY correlations of 1

$R^{*}$, and $\mathrm{H}_{3}-20$ are on the other side. Accordingly, the relative configuration at C-12 was established as $S^{*}$. In a previous paper [7], it was reported that enzymatic hydrolysis of borapetoside D (6) yielded $\mathbf{1}$, the relative configuration at C-12 in 6 was therefore assigned as $S^{*}$.

Compound 2 was obtained as an inseparable C-16 epimeric mixture $(3: 1)$ where some of the signals appeared as duplicate in the NMR spectra (Tables 1, 2). Its molecular formula was determined as $\mathrm{C}_{21} \mathrm{H}_{26} \mathrm{O}_{8}$ from HREIMS at $\mathrm{m} /$ $z 406.1623[\mathrm{M}]^{+}$(calcd 406.1628), requiring 9 degrees of unsaturation. The IR spectrum suggested the presence of hydroxy $\left(3411 \mathrm{~cm}^{-1}\right)$ and carbonyl $\left(1710 \mathrm{~cm}^{-1}\right)$ functionalities. Comparison of its ${ }^{13} \mathrm{C}$ NMR data with that of rumphioside $\mathrm{F}$ (10) [7] revealed a remarkable resemblance except for the absence of a set of glucopyranosyl resonances and the signal assigned to $\mathrm{C}-12$ being upfield ( $\Delta=-6.1 \mathrm{ppm}$ ), which suggested that 2 was an aglycone of rumphioside F. Heteronuclear multiple bond connectivity (HMBC) correlations (Fig. 1) from 12-OH to C-11/ C-12 and from H-12 to C-9/C-11/C-13/C-14 further verified the location of this hydroxy group. The configurations at C-5, C-6, C-8, and C-9 were consistent with those of rumphioside $\mathrm{F}$ (10) according to a careful analysis of the ROESY spectrum. Furthermore, the stereochemistry for C-12 was established by analysis of the proton coupling constants and ROESY data (Fig. 2). The anti relationship of $\mathrm{H}-11$ pro- $R^{*}$ and $\mathrm{H}-12$ and the dihedral angle of $\mathrm{H}-11$ pro- $S^{*} / \mathrm{C}-11 / \mathrm{C}-12 / \mathrm{H}-12$ (ca.90 $0^{\circ}$ is reasonable by two coupling constants $\left({ }^{3} J_{12,11 \text { pro- } R^{*}}=8.4 / 9.1 \mathrm{~Hz}\right.$; ${ }^{3} J_{12,11 \text { pro- } S^{*}} \approx 0 \mathrm{~Hz}$ ) recorded in $\mathrm{CDCl}_{3}$ (Table 1 ). In the ROESY spectrum (Fig. 1) measured in DMSO- $d_{6}$, significant correlations of $\mathrm{H}-12 \leftrightarrow \mathrm{H}-8$ and $\mathrm{H}-11$ pro- $\mathrm{S}_{\leftrightarrow} \leftrightarrow \mathrm{H}-8$ indicated that $\mathrm{H}-12, \mathrm{H}-8$, and $\mathrm{H}-11$ pro- $\mathrm{S}^{*}$ are spatially close to each other. Similarly, correlations of $12-\mathrm{OH} \leftrightarrow \mathrm{Me}-$ 20 and $12-\mathrm{OH} \leftrightarrow \mathrm{H}-11$ pro- $R *$ implied that these protons are cofacial. The relative configurations of other structural
Table $2{ }^{13} \mathrm{C}$ NMR spectroscopic data for $\mathbf{1}$ and $\mathbf{2}$

\begin{tabular}{|c|c|c|c|}
\hline No. & $1^{\mathrm{a}}$ & $2^{\mathrm{b}}$ & $2^{\mathrm{c}}$ \\
\hline 1 & $16.6, \mathrm{CH}_{2}$ & $16.4, \mathrm{CH}_{2}$ & $16.3, \mathrm{CH}_{2}$ \\
\hline 2 & $24.3, \mathrm{CH}_{2}$ & $24.0, \mathrm{CH}_{2}$ & $24.1, \mathrm{CH}_{2}$ \\
\hline 3 & 142.7, CH & $142.8, \mathrm{CH}$ & 143.1, CH \\
\hline 4 & $134.4, \mathrm{C}$ & $133.8, \mathrm{C}$ & $133.9, \mathrm{C}$ \\
\hline 5 & $39.5, \mathrm{C}$ & $39.1, \mathrm{C}$ & $39.1, \mathrm{C}$ \\
\hline 6 & $82.8, \mathrm{CH}$ & $83.9, \mathrm{CH}$ & $82.6, \mathrm{CH}$ \\
\hline 7 & $29.6, \mathrm{CH}_{2}$ & $29.4, \mathrm{CH}_{2}$ & $29.2, \mathrm{CH}_{2}$ \\
\hline 8 & $46.8, \mathrm{CH}$ & 47.7/47.4, CH & $47.1 / 46.8, \mathrm{CH}$ \\
\hline 9 & $39.8, \mathrm{C}$ & $39.4, \mathrm{C}$ & $39.4, \mathrm{C}$ \\
\hline 10 & $45.8, \mathrm{CH}$ & $44.5 / 45.0, \mathrm{CH}$ & $45.0 / 45.6, \mathrm{CH}$ \\
\hline 11 & 47.7, $\mathrm{CH}_{2}$ & 44.1/44.6, $\mathrm{CH}_{2}$ & 44.9/44.1, $\mathrm{CH}_{2}$ \\
\hline 12 & $69.5, \mathrm{CH}$ & $64.6, \mathrm{CH}$ & $64.1 / 63.5, \mathrm{CH}$ \\
\hline 13 & $128.6, \mathrm{C}$ & 173.5/171.0, C & 175.8/173.6, C \\
\hline 14 & $110.5, \mathrm{CH}$ & $116.8 / 117.9, \mathrm{CH}$ & 115.9/116.7, CH \\
\hline 15 & 143.7, $\mathrm{CH}$ & 171.0, C & 171.1, C \\
\hline 16 & $140.8, \mathrm{CH}$ & 97.2/98.1, CH & 98.7/98.0, CH \\
\hline 17 & 178.3, C & 179.7, C & 177.7, C \\
\hline 18 & 166.9, C & 166.6, C & $166.8, \mathrm{C}$ \\
\hline 19 & $27.2, \mathrm{CH}_{3}$ & 27.0, $\mathrm{CH}_{3}$ & $27.3, \mathrm{CH}_{3}$ \\
\hline 20 & 21.6, $\mathrm{CH}_{3}$ & $20.7 / 21.5, \mathrm{CH}_{3}$ & $21.0 / 21.9, \mathrm{CH}_{3}$ \\
\hline $\mathrm{OMe}$ & $51.6, \mathrm{CH}_{3}$ & $51.8, \mathrm{CH}_{3}$ & $52.1, \mathrm{CH}_{3}$ \\
\hline \multicolumn{4}{|l|}{$\mathrm{CH}_{3} \mathrm{CO}$} \\
\hline \multicolumn{4}{|l|}{$\mathrm{CH}_{3} \mathrm{CO}$} \\
\hline $1^{\prime}$ & 101.7, CH & & \\
\hline $2^{\prime}$ & 75.6, CH & & \\
\hline $3^{\prime}$ & 78.6, $\mathrm{CH}$ & & \\
\hline $4^{\prime}$ & $72.2, \mathrm{CH}$ & & \\
\hline $5^{\prime}$ & $78.2, \mathrm{CH}$ & & \\
\hline $6^{\prime}$ & $63.1, \mathrm{CH}_{2}$ & & \\
\hline
\end{tabular}

${ }^{\mathrm{a}}$ Measured in pyridine- $d_{5}\left(\delta_{\mathrm{C}} 149.9 \mathrm{ppm}\right)$

b Measured in $\mathrm{CDCl}_{3}\left(\delta_{\mathrm{C}} 77.0 \mathrm{ppm}\right)$

${ }^{c}$ Measured in DMSO- $d_{6}\left(\delta_{\mathrm{C}} 39.5 \mathrm{ppm}\right)$

parts of $\mathbf{2}$ are identical with those of rumphioside F (10) [7], based on detailed analysis of ROESY spectrum and coupling constants. Hence, the structure of $\mathbf{2}$ were characterized and given the trivial name tinosporol $\mathrm{A}$.

Compound 3 gave a molecular formula of $\mathrm{C}_{23} \mathrm{H}_{26} \mathrm{O}_{8}$ by HREIMS $\left([\mathrm{M}]^{+} \mathrm{m} / \mathrm{z}, 430.1634\right.$, calcd 430.1628). The ${ }^{1} \mathrm{H}$ and ${ }^{13} \mathrm{C}$ NMR data (Tables 3,4) were similar to those of tinocrispol A [2] except for an additional acetyl group $\left(\delta_{\mathrm{H}}\right.$ $\left.2.12 ; \delta_{\mathrm{C}} 21.1,168.7\right)$. This group was attached at $\mathrm{C}-8\left(\delta_{\mathrm{C}}\right.$ 78.1) due to the chemical shift of $\mathrm{C}-8$ in $\mathbf{3}$ showing a downfield shift $(\Delta=4.8 \mathrm{ppm}$ ) relative to that of the corresponding hydroxyl-bearing carbon in tinocrispol $\mathrm{A}$, which was also confirmed by the lack of esterification shift [2] of H-2 in 3 and weak HMBC correlation $\left({ }^{4} J\right)$ from the acetyl proton $\left(\delta_{\mathrm{H}} 2.12\right)$ to $\mathrm{C}$ - 8 . The acetyl group is $\alpha$-oriented as indicated by a clear ROESY correlation between 


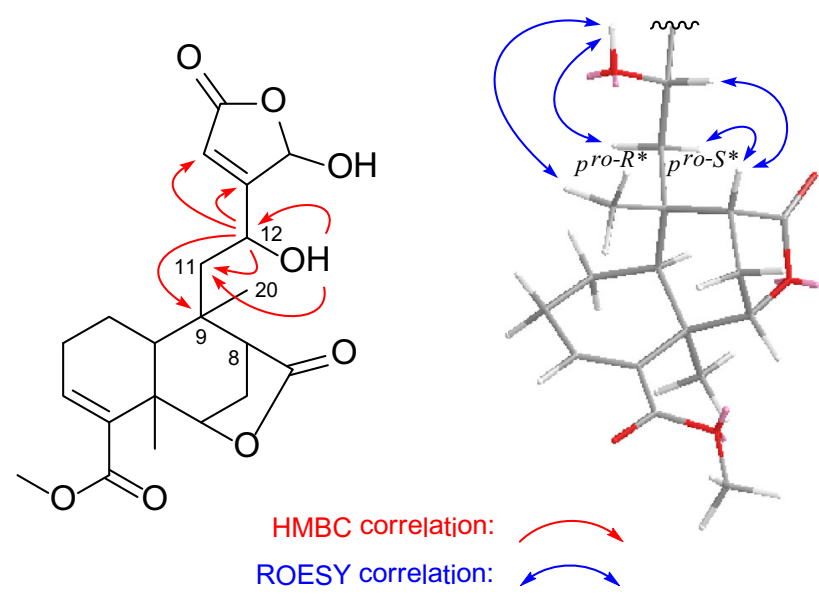

Fig. 2 Key HMBC and ROESY correlations of 2

H-12 and acetyl proton. Consequently, the structure of compound $\mathbf{3}$ was identified as shown, and it was named tinosporol B.

Compound 4 was isolated as an inseparable C-16 epimeric mixture (5:4). It gave a molecular formula of $\mathrm{C}_{21} \mathrm{H}_{24} \mathrm{O}_{7}$ by HREIMS $\left([\mathrm{M}]^{+} \mathrm{m} / z\right.$ 388.1521, calcd 388.1522). The ${ }^{1} \mathrm{H}$ and ${ }^{13} \mathrm{C}$ NMR data (Tables 3, 4) revealed that the compound closely resembled 2 . The only difference was that signals for a methylene (C-11) and a methine $(\mathrm{C}-12)$ in 2 were replaced by a double bond $\left(\delta_{\mathrm{H}}\right.$ $\left.6.50 / 6.53,6.36 / 6.37 ; \delta_{\mathrm{C}} 148.96 / 148.77,119.72 / 119.85\right)$ in 4 on the basis of HMBC correlations from $\mathrm{H}-11$ to $\mathrm{C}-8$, C-10, C-12, C-13, and C-20. The E-geometry of C-11/C-12 olefin was supported by the large coupling constant $\left(J_{11,12}=16.4 \mathrm{~Hz}\right)$ and ROESY correlations of H-11/H-16 and $\mathrm{H}-12 / \mathrm{H}_{3}-20$. Therefore, the structure of compound 4 was determined and named tinosporol $\mathrm{C}$.

Compound 5 had the molecular formula $\mathrm{C}_{27} \mathrm{H}_{36} \mathrm{O}_{12}$, deducing from the HREIMS ([M ${ }^{+} \mathrm{m} / z$ 552.2225, calcd 552.2207). The ${ }^{1} \mathrm{H}$ NMR and ${ }^{13} \mathrm{C}$ NMR spectra (Tables 3 , 4) displayed signals very similar to those of 7 [2]. The principal difference between them was the location of the glucopyranosyl moiety. This moiety was linked to C-2 as indicated by $\mathrm{HMBC}$ correlations from the anomeric proton $\left(\delta_{\mathrm{H}} 4.44\right)$ to $\mathrm{C}-2\left(\delta_{\mathrm{C}} 72.6\right)$. The relative configuration of 5 was determined to be the same as that of 7 , based on detailed analysis of ROESY spectrum and coupling constants. Thus, the structure of $\mathbf{2}$ were established and given the trivial name tinosporoside A.

Based on the usage of T. crispa in TMCs and corrected structure characteristics of the compound $\mathbf{1}$, then the antihyperglycemia activities of compound $\mathbf{1}$ on hyperglycemic mice in vivo were evaluated. Following intravenously administrated compound $\mathbf{1}$ in alloxan-induced hyperglycemic mice which is a fast and classic type 1 diabetes mellitus (T1DM) model in pharmacological study [16]. In our study, alloxan injections markedly increased the serum glucose level from $7.0 \pm 0.5 \mathrm{mM} / \mathrm{L}$ to $24.3 \pm 3.7 \mathrm{mM} / \mathrm{L}$ (Fig. 3). Under this condition, compound 1 (dose of $20 \mathrm{mg} /$ $\mathrm{kg}$ ) was able to induce a significant decrease of blood glucose down to $21.7 \pm 6.7 \mathrm{mM} / \mathrm{L}$ after 5 times administration $(25.9 \pm 2.5 \mathrm{mM} / \mathrm{L}$ before compound treatment), whereas dose of $40 \mathrm{mg} / \mathrm{kg}$ of the compound caused a further down of glucose level to $15.9 \pm 9.2 \mathrm{mM} / \mathrm{L}$, indicating a tendency of dose-dependent effect of the compound on lowing blood glucose in this animal model.

Furthermore, regarding that it is a valuable approach to extensively evaluate the drug effect on animals by evaluating its effect after drug withdrawing. Next we measured blood glucose levels on 3 or 5 days later after withdraw of compound 1. Surprisingly, the blood glucose level was even further down to $17.9 \pm 3.8 \mathrm{mM} / \mathrm{L}$ after 3-days withdrawing for the group of $20 \mathrm{mg} / \mathrm{kg}$ treatment (compared to $21.7 \pm$ $6.7 \mathrm{mM} / \mathrm{L}$ before drug withdrawing, Fig. 3), whereas glucose level after 3-days withdrawing in group of $40 \mathrm{mg} / \mathrm{kg}$ treatment maintained at $16.7 \pm 4.7 \mathrm{mM} / \mathrm{L}$ which was similar to the level before drug withdraw $(15.9 \pm 9.2 \mathrm{mM} / \mathrm{L}$, Fig. 3). Explaining for these results could be the maxim of glucose being recovered by the drug could be $16 \mathrm{mM} /$ $\mathrm{L}$ or so, so that $40 \mathrm{mg} / \mathrm{kg}$ treatment already achieved the maxim level in this approach. After withdrawing drug for 5 days, both glucose levels for groups of 20 or $40 \mathrm{mg} / \mathrm{kg}$ treatment fully recovered to the levels before drug treatments.

Furthermore, we asked that whether the effect of compound $\mathbf{1}$ on lowing blood glucose is specific for alloxaninduced hyperglycemic mice. Therefore we estimated the effect of the compound on $\mathrm{db} / \mathrm{db}$ mice that is genetic animal model of which has been widely used in T2DM study. Compound 1 administration for 5 times slightly decreased glucose levels to $17.85 \pm 2.83 \mathrm{mM} / \mathrm{L}$ of these mice at the dosage of $40 \mathrm{mg} / \mathrm{kg}$ ( $p=0.041$, compared to $21.93 \pm$ $4.10 \mathrm{mM} / \mathrm{L}$ of model mice), whereas a lower dose $(20 \mathrm{mg} /$ $\mathrm{kg})$ didn't affect the glucose level $(19.49 \pm 3.91 \mathrm{mM} / \mathrm{L}$, Fig. 4). Comparing with the strikingly decreased glucose $(8.89 \pm 2.80 \mathrm{mM} / \mathrm{L})$ with $\mathrm{MET}$ administration, we concluded that T1DM mice are more sensitive than T2DM mice to compound $\mathbf{1}$.

\section{Experimental Section}

\subsection{General Experimental Procedures}

Optical rotations were measured on a Jasco P-1020 automatic digital polarimeter. UV spectra were obtained in an HPLC (Agilent 1200, DAD). IR spectra were obtained using a Bruker Tensor 27 FT-IR spectrometer with $\mathrm{KBr}$ pellets. NMR spectra were acquired with a Bruker Avance 
Table $3{ }^{1} \mathrm{H}$ NMR spectroscopic data for $\mathbf{3 - 5}$

\begin{tabular}{|c|c|c|c|}
\hline No. & $3^{\mathrm{a}}$ & $4^{\mathrm{a}}$ & $5^{\mathrm{b}}$ \\
\hline $1 \alpha$ & 2.01, ddd $(14.7,10.5,6.4)$ & $1.94, \mathrm{~m}$ & 2.18, ddd $(14.1,8.1,6.8)$ \\
\hline $1 \beta$ & 2.29, brdd $(14.7,7.3)$ & $1.64, \mathrm{~m}$ & $2.33, \mathrm{dd}(14.1,8.7)$ \\
\hline $2 \alpha$ & 4.56 , ddd $(10.5,7.3,2.6)$ & 2.31-2.37, overlap & $4.69, \operatorname{td}(8.4,4.0)$ \\
\hline $2 \beta$ & & 2.31-2.37, overlap & \\
\hline 3 & 6.72, brs & $7.05, \mathrm{t}(3.7)$ & $6.45, \mathrm{~d}(4.0)$ \\
\hline 6 & $6.58, \mathrm{~d}(10.4)$ & $5.56, \mathrm{t}(5.8)$ & 4.45, brd $(2.4)$ \\
\hline $7 \alpha$ & $6.55, \mathrm{~d}(10.4)$ & $2.22-2.27, \mathrm{~m}$ & 1.91, ddd $(14.1,4.0,2.4)$ \\
\hline $7 \beta$ & & $2.02 / 2.02, \mathrm{~d}(12.6 / 11.9)$ & 1.55, ddd $(14.1,12.1,1.7)$ \\
\hline 8 & & 2.23, overlap/2.28, d (5.3) & 3.35 , overlap \\
\hline 10 & $2.52, \mathrm{dd}(6.4,1.7)$ & $1.84, \mathrm{t}(6.1)$ & $2.21, \mathrm{~d}(6.8)$ \\
\hline 11 pro- $R^{*}$ & 1.97, dd $(13.3,8.7)$ & $6.50 / 6.53, \mathrm{~d}(16.4)$ & 2.00, dd $(14.1,11.6)$ \\
\hline 11 pro-S* & $2.31, \mathrm{dd}(13.3,8.0)$ & & $2.12, \mathrm{dd}(14.1,6.1)$ \\
\hline 12 & $5.59, \mathrm{dd}(8.7,8.0)$ & $6.36 / 6.37, \mathrm{~d}(16.4)$ & $5.49, \mathrm{dd}(11.4,5.9)$ \\
\hline 14 & $6.41, \mathrm{~d}(1.2)$ & $5.92 / 5.93, \mathrm{~s}$ & 6.51, brd $(1.2)$ \\
\hline 15 & $7.43, \mathrm{t}(1.4)$ & & $7.51, \mathrm{t}(1.7)$ \\
\hline 16 & 7.47, brs & $6.31 / 6.26, \mathrm{~s}$ & 7.59, brs \\
\hline 19 & $1.55, \mathrm{~s}$ & $1.37, \mathrm{~s}$ & $1.47, \mathrm{~s}$ \\
\hline 20 & $0.95, \mathrm{~s}$ & $1.29, \mathrm{~s}$ & $0.97, \mathrm{~s}$ \\
\hline $\mathrm{OMe}$ & $3.73, \mathrm{~s}$ & $3.74, \mathrm{~s}$ & $3.74, \mathrm{~s}$ \\
\hline $\mathrm{CH}_{3} \mathrm{CO}$ & $2.12, \mathrm{~s}$ & & \\
\hline \multicolumn{4}{|l|}{$12-\mathrm{OH}$} \\
\hline \multicolumn{4}{|l|}{$16-\mathrm{OH}$} \\
\hline $1^{\prime}$ & & & $4.44, \mathrm{~d}(7.9)$ \\
\hline $2^{\prime}$ & & & $3.14, \mathrm{dd}(9.1,7.9)$ \\
\hline $3^{\prime}$ & & & $3.34, \mathrm{t}(8.9)$ \\
\hline $4^{\prime}$ & & & $3.26, \mathrm{t}(9.0)$ \\
\hline $5^{\prime}$ & & & $3.29, \mathrm{~m}$ \\
\hline \multirow[t]{2}{*}{$6^{\prime}$} & & & $3.65, \mathrm{dd}(11.8,5.8)$ \\
\hline & & & $3.87, \mathrm{dd}(11.8,1.9)$ \\
\hline
\end{tabular}

${ }^{a}$ Measured in $\mathrm{CDCl}_{3}\left(\delta_{\mathrm{H}} 7.26 \mathrm{ppm}\right)$

${ }^{\mathrm{b}}$ Measured in methanol- $d_{4}\left(\delta_{\mathrm{H}} 3.30 \mathrm{ppm}\right)$

III 600 instrument at room temperature. EIMS (including HREIMS) was measured on a Waters AutoSpec Premier P776 spectrometer. Silica gel (200-300 mesh, Qingdao Marine Chemical, Inc., Qingdao, P. R. China), MCI CHP20 (70-150 $\mu \mathrm{m}$, Mitsubishi Chemical Corporation, Japan) and Sephadex LH-20 (Amersham Biosciences, Sweden) were used for column chromatography (CC). Medium pressure liquid chromatography (MPLC) was performed on a Büchi Sepacore System equipping with pump manager C-615, pump modules C-605, and fraction collector C-660 (Büchi Labor technik AG, Switzerland), and columns packed with Chromatorex C-18 (40-75 $\mu \mathrm{m}$, Fuji Silysia Chemical Ltd., Japan). Fractions were monitored by TLC and HPLC (Agilent 1200, Extend-C18 column, $5 \mu \mathrm{m}$, $4.6 \times 150 \mathrm{~mm})$.

\subsection{Plant Material}

The vines of T. crispa were collected in April 2012 in Simao, Yunnan Province, China. The sample was identified by Mr. Yu Chen of Kunming Institute of Botany, Chinese Academy of Sciences. The voucher specimen (No. BBP20120452) was deposited at BioBioPha Co., Ltd.

\subsection{Extraction and Isolation}

The air-dried and powdered vines of T. crispa $(15 \mathrm{~kg})$ were extracted with EtOH- $\mathrm{H}_{2} \mathrm{O}(95: 5$, v/v; $3 \times 25 \mathrm{~L}$, each 5 days) at room temperature, and the solvent was removed under reduced pressure to give crude extract (ca. $1100 \mathrm{~g}$ ), which was fractionated by silica gel CC successively eluted 
Table $4{ }^{13} \mathrm{C}$ NMR spectroscopic data for $3-5$

\begin{tabular}{|c|c|c|c|}
\hline No. & $3^{\mathrm{a}}$ & $4^{\mathrm{a}}$ & $5^{\mathrm{b}}$ \\
\hline 1 & $28.2, \mathrm{CH}_{2}$ & $16.9, \mathrm{CH}_{2}$ & $26.7, \mathrm{CH}_{2}$ \\
\hline 2 & $64.4, \mathrm{CH}$ & $23.9, \mathrm{CH}_{2}$ & $72.6, \mathrm{CH}$ \\
\hline 3 & 139.6, CH & $142.79 / 142.66, \mathrm{CH}$ & $138.5, \mathrm{CH}$ \\
\hline 4 & $136.5, \mathrm{C}$ & 133.78/133.81, C & $141.8, \mathrm{C}$ \\
\hline 5 & $37.3, \mathrm{C}$ & $38.6, \mathrm{C}$ & $41.9, \mathrm{C}$ \\
\hline 6 & $138.0, \mathrm{CH}$ & $83.30 / 83.18, \mathrm{CH}$ & $69.3, \mathrm{CH}$ \\
\hline 7 & $120.8, \mathrm{CH}$ & $29.83 / 29.81, \mathrm{CH}_{2}$ & $28.5, \mathrm{CH}_{2}$ \\
\hline 8 & 78.1, C & $50.86 / 50.71, \mathrm{CH}$ & $41.3, \mathrm{CH}$ \\
\hline 9 & $39.2, \mathrm{C}$ & $42.47 / 42.42, \mathrm{C}$ & $38.3, \mathrm{C}$ \\
\hline 10 & $45.3, \mathrm{CH}$ & $41.31,41.40, \mathrm{CH}$ & $51.0, \mathrm{CH}$ \\
\hline 11 & $39.4, \mathrm{CH}_{2}$ & $148.96 / 148.77, \mathrm{CH}$ & $46.2, \mathrm{CH}_{2}$ \\
\hline 12 & $70.9, \mathrm{CH}$ & $119.72 / 119.85, \mathrm{CH}$ & $72.0, \mathrm{CH}$ \\
\hline 13 & $125.7, \mathrm{C}$ & 160.66/160.63, C & $126.0, \mathrm{C}$ \\
\hline 14 & $108.3, \mathrm{CH}$ & 117.28/117.26, CH & $109.9, \mathrm{CH}$ \\
\hline 15 & $144.0, \mathrm{CH}$ & $170.92 / 170.87, \mathrm{C}$ & $145.0, \mathrm{CH}$ \\
\hline 16 & $139.4, \mathrm{CH}$ & 97.54/97.46, CH & $141.4, \mathrm{CH}$ \\
\hline 17 & $167.3, \mathrm{C}$ & 177.61/177.56, C & $178.3, \mathrm{C}$ \\
\hline 18 & 166.6, C & $166.5, \mathrm{C}$ & 169.9, C \\
\hline 19 & $30.3, \mathrm{CH}_{3}$ & $26.9, \mathrm{CH}_{3}$ & $29.7, \mathrm{CH}_{3}$ \\
\hline 20 & $23.1, \mathrm{CH}_{3}$ & $19.15 / 19.12, \mathrm{CH}_{3}$ & $23.5, \mathrm{CH}_{3}$ \\
\hline $\mathrm{OMe}$ & $51.9, \mathrm{CH}_{3}$ & $51.8, \mathrm{CH}_{3}$ & $52.4, \mathrm{CH}_{3}$ \\
\hline $\mathrm{CH}_{3} \mathrm{CO}$ & $21.1, \mathrm{CH}_{3}$ & & \\
\hline $\mathrm{CH}_{3} \mathrm{CO}$ & 168.7, C & & \\
\hline $1^{\prime}$ & & & 103.6, CH \\
\hline $2^{\prime}$ & & & 75.0, $\mathrm{CH}$ \\
\hline $3^{\prime}$ & & & 78.0, $\mathrm{CH}$ \\
\hline $4^{\prime}$ & & & 71.6, CH \\
\hline $5^{\prime}$ & & & 77.9, $\mathrm{CH}$ \\
\hline $6^{\prime}$ & & & $62.7, \mathrm{CH}_{2}$ \\
\hline
\end{tabular}

${ }^{a}$ Measured in $\mathrm{CDCl}_{3}\left(\delta_{\mathrm{C}} 77.0 \mathrm{ppm}\right)$

b Measured in methanol- $d_{4}\left(\delta_{\mathrm{C}} 49.0 \mathrm{ppm}\right)$

with petroleum ether $(\mathrm{PE}) /$ acetone $(99: 1 \rightarrow 0: 100$ gradient $)$ to give seven fractions $\mathrm{A}-\mathrm{G}$.

Fraction $\mathrm{C}(11 \mathrm{~g})$ was subjected to MPLC using a stepwise gradient of $\mathrm{MeOH} / \mathrm{H}_{2} \mathrm{O}(0 \rightarrow 100 \%)$ to give fractions $\mathrm{C} 1-\mathrm{C} 4$. Fraction $\mathrm{C} 2$ was separated by MPLC $\left(\mathrm{MeOH} / \mathrm{H}_{2} \mathrm{O}, 45 \%\right)$, followed by prep. TLC $\left(\mathrm{CHCl}_{3} /\right.$ $\mathrm{MeOH}, 20: 1)$ to obtain $2(27 \mathrm{mg})$. After repeated silica gel $\mathrm{CC}\left(\mathrm{CHCl}_{3} / \mathrm{MeOH}, 50: 1\right)$, fraction $\mathrm{C} 3$ afforded the precipitate 3 (30 mg).

Fraction E $(180 \mathrm{~g})$ was separated by silica gel CC $\left(\mathrm{CHCl}_{3} / \mathrm{MeOH}, 40: 1 \rightarrow 5: 1\right)$ into fractions E1-E3. Fraction E1 was chromatographed over a Sephadex LH-20 column $(\mathrm{MeOH})$ repeatedly to yield $\mathbf{1}(5.3 \mathrm{~g})$ and $\mathbf{8}(331 \mathrm{mg})$, respectively. Fraction E2 was subjected to $\mathrm{MCI}(\mathrm{MeOH} /$ $\left.\mathrm{H}_{2} \mathrm{O}, 45 \rightarrow 50 \%\right)$ and then Sephadex LH-20 (MeOH) CC to
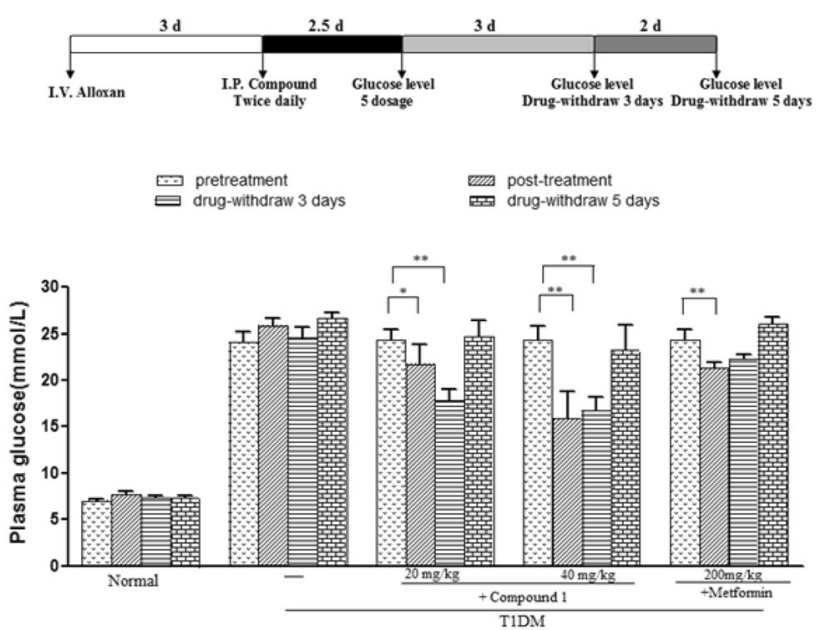

Fig. 3 Effect of compound 1 on alloxan-induced hyperglycemia mice. Experimental procedure was shown above. Data are shown as mean \pm SEM $\left(\mathrm{n}=10\right.$ in each group). ${ }^{*} P<0.05,{ }^{*} P<0.01$ (Dunnett's test). Metformin served as a positive control

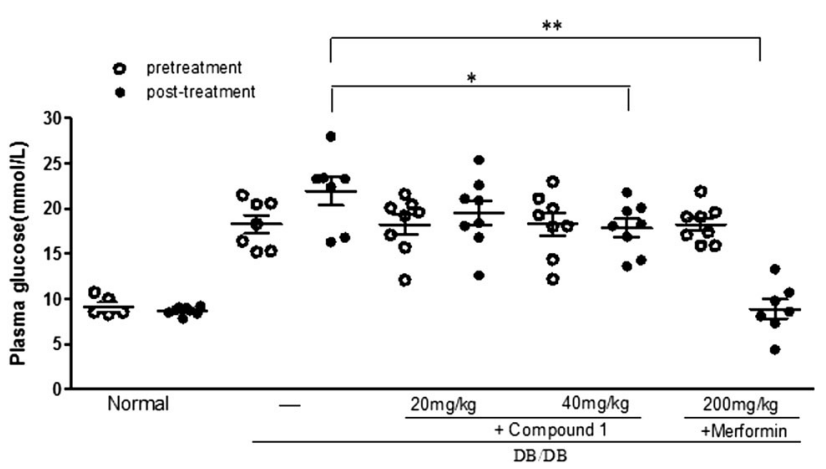

Fig. 4 Effects of compound 1 on glucose levels of $\mathrm{db} / \mathrm{db}$ mice. Data are presented as mean \pm SEM $(\mathrm{n}=10$ in each group). $* P<0.05$, $* * P<0.01$ (Dunnett's test). Metformin served as a positive control

give $\mathbf{5}(4 \mathrm{mg})$ and $\mathbf{1 0}(46 \mathrm{mg})$, respectively. The latter was unstable, and after the 1D NMR experiment followed by freeze drying, converted to a product less polar than $\mathbf{1 0}$, which afforded $4(18 \mathrm{mg})$ after silica gel $\mathrm{CC}\left(\mathrm{CHCl}_{3} /\right.$ $\mathrm{MeOH}, 20: 1)$. Compounds 7 (2.3 g) and $9(98 \mathrm{mg})$ were obtained from fraction E3 by chromatography on a silica gel column $\left(\mathrm{CHCl}_{3} / \mathrm{MeOH}, 9: 1\right)$.

Fraction F (90 g) was separated by silica gel CC $\left(\mathrm{CHCl}_{3} / \mathrm{MeOH}, 5: 1 \rightarrow 3: 1\right)$ into fractions $\mathrm{F} 1$ and $\mathrm{F} 2$. Compound $6(162 \mathrm{mg})$ was obtained from $\mathrm{F} 2$ by $\mathrm{MCI} \mathrm{CC}$ $\left(\mathrm{MeOH} / \mathrm{H}_{2} \mathrm{O}, 5 \rightarrow 25 \%\right)$.

\subsubsection{Tinosporol A (2)}

White, amorphous powder; $[\alpha]_{\mathrm{D}}^{28}-113.4\left(c 0.05, \mathrm{CHCl}_{3}\right)$; $\mathrm{UV}(\mathrm{MeOH}) \lambda_{\max }: 213 \mathrm{~nm}$; IR (KBr) $v_{\max } 3441,2951$, 1762, 1710, 1634, 1437, 1352, 1270, 1242, 1154, 1104, 1074, 952, $906 \mathrm{~cm}^{-1} ;{ }^{1} \mathrm{H}$ and ${ }^{13} \mathrm{C}$ NMR data, see Tables 1 
and 2; EI-MS: $m / z 406[\mathrm{M}]^{+}(12), 388$ (13), 391 (62), 328 (13), 278 (28), 263 (28), 235 (100), 203 (90), 185 (22), 152 (18), 93 (29), 91 (32); HR-EI-MS: $m / z 406.1623$ (calcd for $\left.\mathrm{C}_{21} \mathrm{H}_{26} \mathrm{O}_{8}, 406.1628\right)$.

\subsubsection{Tinosporol B (3)}

White, amorphous powder; $[\alpha]_{\mathrm{D}}^{27}-147.2\left(\right.$ c $\left.0.05, \mathrm{CHCl}_{3}\right)$; UV (MeOH) $\lambda_{\text {max }}: 213 \mathrm{~nm}$; IR (KBr) $v_{\max } 3442,2952$, 1758, 1715, 1634, 1437, 1371, 1232, 1156, 1106, 1072, 1024, 1007, 876, $780 \mathrm{~cm}^{-1} ;{ }^{1} \mathrm{H}$ and ${ }^{13} \mathrm{C}$ NMR data, see Tables 3 and 4; EI-MS: $m / z 430\left[\right.$ [M] $^{+}$(10), 399 (10), 370 (28), 342 (30), 294 (100), 262 (41), 203 (52), 173 (37), 122 (72), 95 (70), 91 (59); HR-EI-MS: $\mathrm{m} / \mathrm{z} 430.1634$ (calcd for $\left.\mathrm{C}_{23} \mathrm{H}_{26} \mathrm{O}_{8}, 430.1628\right)$.

\subsubsection{Tinosporol $C(4)$}

White, amorphous powder; $[\alpha]_{\mathrm{D}}^{28}-133.6\left(c 0.05, \mathrm{CHCl}_{3}\right)$; UV (MeOH) $\lambda_{\max }: 208,262 \mathrm{~nm}$; IR (KBr) $v_{\max } 3432$, 2949, 1760, 1710, 1641, 1452, 1436, 1351, 1268, 1243, 1228, 1181, 1160, 1223, 1101, 975, $953 \mathrm{~cm}^{-1} ;{ }^{1} \mathrm{H}$ and ${ }^{13} \mathrm{C}$ NMR data, see Tables 3 and 4; EI-MS: $m / z 388[\mathrm{M}]^{+}(75)$, 370 (30), 357 (33), 338 (48), 181 (50), 153 (100), 149 (61), 105 (49), 93 (83), 91 (75), 83 (60), 77 (61); HR-EI-MS: m/z 388.1521 (calcd for $\mathrm{C}_{21} \mathrm{H}_{24} \mathrm{O}_{7}, 388.1522$ ).

\subsubsection{Tinosporoside A (5)}

White, amorphous powder; $[\alpha]_{\mathrm{D}}^{26}-78.7$ ( $c 0.05, \mathrm{CHCl}_{3}$ ); UV (MeOH) $\lambda_{\text {max }}: 214 \mathrm{~nm}$; IR (KBr) $v_{\max } 3442,2925$, 1720, 1632, 1440, 1383, 1252, 1158, 1101, 1073, 1026, $602 \mathrm{~cm}^{-1}$; ${ }^{1} \mathrm{H}$ and ${ }^{13} \mathrm{C}$ NMR data, see Tables 3 and 4; EIMS: $m / z, 552\left[\mathrm{M}^{+}\right.$(7), 390 (13), 372 (15), 309 (40), 284 (29), 119 (48), 91 (68), 69 (100); HR-EI-MS: m/z 552.2225 (calcd for $\mathrm{C}_{27} \mathrm{H}_{36} \mathrm{O}_{12}, 552.2207$ ).

\subsection{Anti-hyperglycemia Activity}

Male ICR and $\mathrm{db} / \mathrm{db}$ mice were obtained from Beijing HFK Bioscience CO., LTD (Certificate No. SCXK 2014-0004) or Nanjing Biomedical Research Institute of Nanjing University (Certificate No. SCXK 2010-0001) respectively. These animals were housed in a temperature and humiditycontrolled room with a 12-hour light/dark cycle. Animals were given ad libitum access to food and water throughout the study. All of the procedures were performed in accordance with the Institute Ethical Committee for Experimental Animal Use. For inducing hyperglycemic mice, 8-week-old ICR mice were intravenously injection with freshly prepared alloxan $(60 \mathrm{mg} / \mathrm{kg})$. Serum glucose level was measured with glucose kit (Changsha Sinocare Inc., China). The mice with plasma glucose level greater than
$11.1 \mathrm{mM} / \mathrm{L}$ were considered diabetic. Animals were treated with the compound 1 or MET twice daily for 2.5 days at the doses 20,40 or $200 \mathrm{mg} / \mathrm{kg}$ as indicated in the figures.

\subsection{Statistical Analysis}

The data were presented as mean \pm SEM, subjected to one-way analysis of variance followed by Dunnett's multiple comparison tests using GraphPad Prism version 5.0 software. ${ }^{*} P<0.05$, $* * P<0.01$.

Acknowledgments This work was financially supported by "Largescale Compound Library" Project of National Development Reform Commission of China, National Natural Science Foundation of China (81561148013 to J.L.), the Chinese Academy of Sciences (292013312 D11004 to W.X.), Yibin University (2015QD06 to Y.G.), and Sciences Foundation of Yunnan Province (39Y33H521261 to W.X.).

Author Contributions Y. N., Y. G., J. L. and W. X. designed research; Y. N. and Y. G. performed research; Y. N. and Y. G. analyzed data; and Y. N., Y. G., W. X. and J. L. wrote the paper.

\section{Compliance with Ethical Standards}

Conflict of Interest The authors declare no competing financial interest.

Open Access This article is distributed under the terms of the Creative Commons Attribution 4.0 International License (http:// creativecommons.org/licenses/by/4.0/), which permits unrestricted use, distribution, and reproduction in any medium, provided you give appropriate credit to the original author(s) and the source, provide a link to the Creative Commons license, and indicate if changes were made.

\section{References}

1. Editorial Committee of Flora Republicae Popularis Sinicae (Academic Press, Beijing, 1996); Vol. 30, p. 20

2. S.H. Lam, C.T. Ruan, P.H. Hsieh, M.J. Su, S.S. Lee, J. Nat. Prod. 75, 153-159 (2012)

3. C.T. Ruan, S.H. Lam, T.C. Chi, S.S. Lee, M.J. Su, Phytomedicine 19, 719-724 (2012)

4. Q. Jia, X. Liu, X. Wu, R. Wang, X. Hu, Y. Li, C. Huang, Phytomedicine 16, 744-750 (2009)

5. Y. Xu, L. Wang, J. He, Y. Bi, M. Li, T. Wang, L. Wang, Y. Jiang, M. Dai, J. Lu, M. Xu, Y. Li, N. Hu, J. Li, S. Mi, C.S. Chen, G. Li, Y. Mu, J. Zhao, L. Kong, J. Chen, S. Lai, W. Wang, W. Zhao, G. Ning, JAMA 2013(310), 948-959 (2010)

6. C.K. Chiang, T.I. Ho, Y.S. Peng, S.P. Hsu, M.F. Pai, S.Y. Yang, K.Y. Hung, K.D. Wu, Diabetes Care 30, 3-7 (2007)

7. H.Y. Chen, X.L. Ye, X.L. Cui, K. He, Y.N. Jin, Z. Chen, X.G. Li, Fitoterapia 83, 67-73 (2012)

8. G.R. Zimmermann, J. Lehar, C.T. Keith, Drug Discov. Today 12, 34-42 (2007)

9. Y. Gao, G.Q. Wang, K. Wei, P. Hai, F. Wang, J.K. Liu, Org. Lett. 14, 5936-5939 (2012)

10. Y. Gao, A.L. Yu, G.T. Li, P. Hai, Y. Li, J.K. Liu, F. Wang, Fitoterapia 107, 44-48 (2015) 
11. Y. Gao, D.S. Zhou, P. Hai, Y. Li, F. Wang, Nat. Prod. Bioprospect. 5, 247-253 (2015)

12. T.S. Martin, K. Ohtani, R. Kasai, K. Yamasaki, Phytochemistry 42, 153-158 (1996)

13. N. Fukuda, M. Yonemitsu, T. Kimura, Liebigs Ann. Chem. 5, 491-495 (1993)
14. M.I. Choudhary, M. Ismail, K. Shaari, A. Abbaskhan, S.A. Sattar, N.S. Lajis, A.U. Rahman, J. Nat. Prod. 73, 541-547 (2010)

15. T.S. Martin, K. Ohtani, R. Kasai, K. Yamasaki, Phytochemistry 40, 1729-1736 (1995)

16. T. Ohno, J. Kitoh, K. Yamashita, Y. Ichikawa, F. Horio, M. Terada, S. Tanaka, T. Namikawa, Life Sci. 63, 455-462 (1998) 